\title{
The Influence of Implementing Role-play as an Educational Technique on EFL Speaking Development
}

\author{
Maria Asuncion Rojas \\ Universidad Técnica de Machala, Machala, Ecuador \\ Jhonny Villafuerte \\ Universidad Laica Eloy Alfaro, Manabí, Ecuador
}

\begin{abstract}
The present study aims to explore the influence of implementing Role-play (RP) as a technique in English class to boost EFL learners' speaking skills in Ecuador. This work analyzes the features of RP from its origin in Psychodrama and the teaching and learning approaches that support this technique as Task-Based Learning (TBLT), Cooperative Learning (CL), Communicative Learning Teaching (CLT), and English for Specific Purposes (ESP). Consequently, RP is an educational technique which exposes learners to experience in genuine situations to strengthen learners' abilities for communicating naturally and meaningfully with their peers about events of their daily routines and future professional environments.
\end{abstract}

Index Terms - teaching technique, language acquisition, English as a foreign language, Higher education, Ecuador

\section{INTRODUCTION}

This study discusses the significance of Role-play (RP) as a positive complement to the English speaking development of EFL learners to function appropriately in real-life situations. The present study analyzes RP origins, definitions, contributions, and supporting approaches to understanding the benefits of this strategy to strengthen oral skills. A literature review exploration is performed to accurately analyze the features of RP from its origins in Psychodrama until its supporting approaches of TBLT, CL, CLT, and ESP.

The results show that the characteristics of RP include dramatic methods since RP is one of the most used techniques of Psychodrama which according to Moreno (1987) is a science that analyzes reality through dramatization. In addition, RP contributes to the development of communication skills since it offers opportunities to practice a foreign language socially with their peers. RP also offers appropriate learning environments in which students participate in a more fearless environment to practice English in a realistic way. Furthermore, RP improves learners' speaking skills even though it promotes chaos among students.

Together with these features, RP is supported by TBLT, CL, CLT, and ESP approaches which allow learners develop their conversational skills collaboratively with their peers through the completion of tasks that resemble genuine situations related to their daily life or professional field. In TBLT people try, from the very start of their learning process, to comprehend and produce meaningful messages in English (Task-Based Teaching, 2016). For this reason, TBLT activities are authentic examples of what learners will experience in real-life situations (Bygatte, 2015). In CL, students improve their skills to communicate socially by working collaboratively in groups in the achievement of a common goal (Laguador, 2014). A specific aspect of this approach is that teachers do not have full control over the students, but they become facilitators of new knowledge. In CLT students are encouraged to express their ideas naturally rather than focusing on the form (Alhosni, 2014). Finally, in ESP certain groups of students learn specific English related to their careers. The ESP approach provides learners with opportunities to learn English naturally (Bracaj, 2014) and to become competitive in the job market.

\section{ROLE-PLAY: ORIGINS AND DEFINITION}

RP has its origins in the psychodrama which is a form of psychotherapy, created by Levy Moreno.

The sources of psychodrama are to be found in my childhood games and youthful experiences. One Sunday afternoon, while my parents were out, it so happened that I and some of the neighbors' children decided to play at "God" in the enormous cellar of the house in which I lived. The first thing was to build our Heaven. To this end, we collected every available chair and piled them up on an enormous oak table until they reached to the ceiling. I now mounted my heavenly throne -mine "the kingdom, the power, and the glory" -while my angels "flew" round me singing. Suddenly one of the children called out: "Why don't you fly too?" Whereupon I stretched out my arms-and one 
second later lay on the floor with a broken arm. So ended my first psychodrama, in which I had filled the dual roles of producer and chief actor (Moreno, 2017, p. 131).

Moreno (1987) defines Psychodrama as "the science which explores the truth by dramatic methods" (p. 13). It uses five instruments -the stage, the actor, the director, the staff. and the audience (Moreno, 1987). Among the different techniques of psychodrama, role-playing is the most used in the educational area since according to Moreno (as cited by Martinez, 2009), education should encourage spontaneity and creativity as essential matters for human development and as one of the bases for the social change.

The term 'role' comes from the Greek word 'rolled-up' which refers to theater's scripts used during the ancient Greek times (Craciun, 2010). Role-Plays (RP) also emerged from the games "Simulate Society" (1966) and "Dungeons \& Drangons Fights" (1974) created to involve participants' feelings and emotions using heroic and fantasy elements.

Conforme and Torres (2013) defined RP as a recreational activity that entertains, amuses, and enables participants to acquire new knowledge in a significant way. During RP planning, students also choose the vocabulary and coherent expressions to the situations to play (Waffa, 2014), promoting participants' creativity through collaborative learning routines.

Kusnierek (2015) defined RP as a "complete range of communication technique which develops language fluency and promotes student interaction during the class, increasing students' motivation, encouraging their learning, but also sharing responsibilities between teacher-student" (p.7).

$\mathrm{RP}$ is a teaching technique based on the pedagogical psychodrama, which requires the participants' dedication and interest to complete every stage (Perez, 2016), but also, teacher supervision to avoid participants' extreme reactions that could emerge as a result of the group problem solving (Rojas, et al. 2017).

\section{Contributions of Role-Play for StUdents’ Speaking SKILls Development}

\section{A. Students' Communication Skills Improvement}

RP allows learners to improve their communication skills such as argumentation, the organization of ideas, group understanding, interpretation and inferring (Zhang, 2010). Role-plays (RP) offers multiple opportunities to practice a foreign language than any other teaching activity (Lee and Smagorinsky, 2000; and Gass and Mackey, 2006). It also strengthens students' confidence to use English as a Foreign Language in contextualized environments (Zhang, 2010; Duxbury and Ling, 2010, Asensio, 2015).

A study conducted by Yen, Huei, \& Kuo (2013) analyzed an EFL instructional course by combining Facebook and Skype as platforms through which students participated in role-playing activities and observe the impact of the course on the learner's communication skills. The results show that students developed their speaking abilities through the learning tools and role-playing tasks. Consequently, Role-playing is a significant technique that centers on the learners' ability to speak and communicate by playing various roles in a genuine situation (Yen, Huei, \& Kuo, 2013).

Students need to be motivated to communicate ideas and feelings using any target language (Wafaa, 2014) but also practice their "quality of thought, argumentation, analysis, synthesis, explanation, evaluation on the usage of the foreign language" (Marin and De La Pava, 2017, p. 86).

\section{B. Improve Learning Environments}

Jacobs and McCafferty (2006) maintain that any language practices are more efficient when the learning groups are relatively smaller. Under such conditions, students are supported by a stimulating environment that encourages them to learn a new language.

To Gass and Mackey (2006) RP's main contribution is to involve learners in a fun environment avoiding rivalry and competition among learners. Meanwhile, Huang (2008) argues that teaching and learning plans that include RP had created more adequate atmospheres for learning a foreign language; and helping students to practice English in a more realistic way.

According to Monsalve, Franco, Monsalve, Betancur, and Ramírez (2009), RP enhances students to apply language feedback and reduce peers' confrontations. It also promotes a two-way relationship between teachers and students to reach higher levels of the foreign language domain. The idea is to expose students to a wider range of opportunities for acquiring a foreign language under appropriate environments (Zhang, 2010). Finally, it is necessary teachers learn how to create friendly learning environments, which interacts different methods as active analogic teaching, and educational technology online (Raja, Qureshi and Albesher, 2017).

\section{Improve Learners' Speaking Skills}

Role-play (RP) is a practice of functional language that allows the application of different corrective styles, such as error correction, self-correction, peer correction, etc., among English language students (British Council, 2004). However, some teachers refuse to implement RP, because it promotes chaos into the classroom (noise, laughter, shouting, and disorder). Nevertheless, many studies have been performed on the benefits of RP as a teaching technique that improves students' English speaking skills.

To Duxbury and Ling (2010), when teachers use RP they should motivate learners to perform as best as possible, avoiding instructor's interference. Thus, students live more memorable experiences to emerge higher knowledge 
retention (Tran, 2014). However, RP is a versatile teaching technique that can be applied using different contents and contexts with the active participation of children and adults (Perez, 2016).

To professor Kumaran (2017), learners enjoy participating in RP using a foreign language. Students' participation enables them to communicate without hesitation and fear in real-life contexts strengthening their process of foreign language acquisition.

Instructors should be willing to implement every kind of techniques such as RP to improve speaking skills in the English class such as songs, indoor games, movement, information and communication technologies, etc. (British Council, 2004). They assume the role as a learning process mediator to supply students' feedback-learning and motivation (Mackey, 2006, p.246).

Nation and Newton (2009, p. 112) identified five possible causes of learners' reluctance to speak English which includes "inadequate vocabulary, limited control of grammar, lack of fluency, learners' shyness, and lack of encouragement". However, RP supports educator's abilities to "create a safe learning environment; provide constructive and goal-directed feedback; and cultivate the ability to communicate" (Jackson and Back, 2011, p.3).

Communication is a human process which demands learners to develop multiple and complex abilities. This could be the cause of learners' reluctance when trying to use a foreign language (Nation and Newton, 2009). Nevertheless, they use "their knowledge to express or narrate thoughts and ideas [...] focusing on the communicative and effective factors" (Zhang, 2010, p.83). For this reason, teachers should help to build an appropriate, stimulating and collaborative environment inside the classrooms.

Speaking skills also involve oral expression and phonetic exercises to communicate others: needs, thoughts, emotions, desires, and feelings (Duxbury and Ling, 2010). Consequently, the role of interlocutors and listeners are highly relevant to interpret a spoken message (Monsalve, et al. 2009).

The communication process involves two main moments: the first one takes place at the beginning of a conversation to transmit information; the second moment takes place when people focus on the intonation, pronunciation, grammar structures, ideas organization, types of speech, syntax, morphology, etc. (Peterson, Pisoni and Miyamoto, 2010). To Marin and Rea (2014) the main goal of teaching English is to develop the language acquisition process in a natural way. A teaching method that involves active learning seems to be more efficient among younger students (Peko and Varga, 2014). In addition, teachers should encourage learners "to think critically, [...] developing discussions, tasks and tests that evaluate their performance based on individual and cooperative criteria" (Marin and De la Pava, 2017, p.86). RP becomes a key strategy because it has the flexibility to bring any kind of topic to the classroom (Rojas, et al. 2017).

Behind the foreign language teaching and learning process, there is a lot of hard autonomous work. Thus, it is necessary the active participation and compromise of enthusiastic teachers who can encourage learners to use the target language by themselves (Cevallos, Intriago, Villafuerte, Molina and Ortega, 2017).

\section{ENGLish LANGUAge TEACHING AND LEARNING APPROACHES INVOLVED IN ROLE-PLAY}

\section{A. Task-based Learning and Teaching (TBLT)}

Long (as cited in Branden, 2016) was discontent with the fact that many classes, language were approached as a mechanic system of rules in decontextualized fashion. In this regard, learners had to learn the information about a linguistic item, and then practice the item in sentences that were not related to a real situation until they learn it; only then learners were encouraged to use the linguistic item for communicative purposes. According to Long, this approach does not consist of the way people learn a language.

On the other hand, in natural, non-classroom-based processes of language acquisition, people from the very early stage of learning, strive to understand and produce meaningful messages in the target language. Tourists at the beginner levels, may be eager to pick up words and phrases they need to move around in a foreign country; adolescents who are absorbed in digital game are also eager to acquire the vocabulary they need to play the game; immigrants with a new job in their new country may be motivated to try to understand/produce significant messages related to their job (TaskBased Teaching, 2016).

According to Bygatte (2015), activities that resemble real-life contexts provide 'situational authenticity'. In other words, TBLT tasks are authentic examples of what the learners will experience outside the classroom.

For this reason, Bygatte (2015) considers that knowledge is structured via the learner's experience when interacting in the real world, in order "to be used fluently and appropriately in real time, in real contexts, and with the purposes of engaging real meanings with real people" (p 2).

In addition, the study conducted by East (2017) maintains that the TBLT approach provides an adequate and motivating environment for learning. Teachers should motivate students learning process through the creation of innovative educational environments that generate memorable learning experience under collaborative and communicational approaches (Rojas, Villafuerte and Soto, 2017).

\section{B. Cooperative Learning (CL) Approach}

Students who work together in groups improve their skills to communicate in social discussion and participate in the accomplishment of their common goal. Students with a low performance benefit from this approach when they have the help of high performing students. The exercise is effective for both of them since strong students can increase their 
ability to explain the procedure to the weak students and the process would keep them socially prepared with concern for one another. Therefore, cooperative learning approach in the classroom boosts learners' active involvement (Laguador, 2014).

Cooperative Learning is a task-based and group-structured educational approach in which participants in groups collaborate with each other to look for achievements that are advantageous to each member with the teacher's educational and proper assistance. In this approach teachers are no longer controllers of the students' learning behaviors but promoters of their knowledge. In other words, students become active explorers and constructors of knowledge (Han, 2014).

Students, who are part of CL groups, have initiatives and responsibilities for their own learning achieving different roles as group leaders, participants, and mediators. They create knowledge by researching, negotiating and engaging (Han, 2014). Furthermore, according to Brecke and Jensen (2007), a learning environment mixed with a cooperative learning approach can generate higher levels of efficiency.

Cooperative learning is an approach related to student-centered classroom activities to attain a common goal. For this purpose, the teacher needs to prepare the activities properly to obtain outstanding learning practice on the part of the students. Furthermore, learners have a sense of direction towards the achievement of the group goals when they are provided with clear objectives of the classroom tasks. Everyone is an important active member of the team. The teachers, in this regard, should set the environment favorable for learning (Laguador, 2014).

Cooperative learning also creates future leaders where dedication and commitment to serve the group is an experience that would cultivate their leadership skills. It is also a responsibility of everyone in the academic community to provide an outcomes-based environment that would help shape the character and values of the learners. The support of the management in providing resources to sustain the implementation of Outcomes-based education is an important aspect of success. The learning outcomes of the students gained from the cooperative learning serve as an essential product in an effort to provide quality education for the future leaders of the world (Laguador, 2014, p. 53).

\section{Communicative Learning Teaching (CLT) Approach}

Previous studies of the needs of European language learners, specifically a research prepared by a British linguist, D. A. Wilkins (1972), offered a communicative description of the language that would serve as a foundation for developing communicative syllabuses for language teaching. Wilkins contributed with an analysis of the communicative meanings that a language student requires to comprehend and express. Rather than using the traditional method of language teaching, Wilkins tried to show the systems of meanings to communicate through language (Richards \& Rodgers, 1986).

In order for the curriculum to provide students with regular chances of speaking, communicative activities need to be prepared for students to practice. Those tasks should center on having learners to express the meaning rather than the form. This helps students learn the language more easily as many scientists support the idea that relating students in extracurricular activities can offer them with more opportunities to use the language besides the classroom (Alhosni, 2014).

According to Matamoros, Rojas, Pizarro, Vera, and Soto (2017), through CLT “educators give language Learners opportunities to interact with the new language in situations similar to those they experienced when developing their mother tongue" (p. 968)

Teachers, who teach classes under the CLT Approach, have students participate in tasks where they apply their language knowledge by interacting with their peers. In this respect, Role-plays is one example of the techniques for this approach (Matamoros, Rojas, Pizarro, Vera and Soto, 2017). The research conducted by Flores and Cedeno (2016) in Ecuador determined that the Communicative Approach seems to be highly efficient for enabling learners to communicate orally in any context.

On the contrary, according to Alharby (2015), the absence of authentic language learning situations outside the classroom presents a major challenge to improving students' English communication skills. Furthermore, there are difficulties inside the classroom that limit the use of English, which affect the English speaking ability. In the Saudi EFL situation, Alharby's research tried to identify the reasons for Saudi students' low proficiency in English communication and offer some recommendations.

The most significant findings of the paper were: (1) reforming specific Ministry of Education and Higher Education policies in Saudi Arabia is crucial; (2) the Saudi education system should reinforce the use of contemporary approaches to teaching that emphasise problem-solving and critical thinking skills and put students in charge of their own learning; and (3) the ministry should consider converting some Saudi public schools into bilingual schools (Alharby, 2015, p. 105).

Another study conducted by Farooq (2015) centers on teachers' perceptions and practices concerning CLT and its influence on communicative skills of the learners. The results of the study propose that regardless of viewing strong interest in change and wanting to implement CLT, they are not enthusiastic about the complete implementation of this approach because of the problems and challenges they face in the classroom. Despite the acceptance of CLT during approximately forty years, its viability of implementation has been discussed in EFL situations worldwide. In Saudi universities, there are a significant number of English language teachers who are aware of the CLT and are applying it in their classroom to develop the communicative ability of the learners. In addition, the curriculum is another aspect to 
develop the communicative skill of the students. Nowadays, the majority of universities in Saudi Arabia have implemented communicative syllabus centering on the use of language to communicate rather than to teach rules of grammar to learn. Nevertheless, CLT cannot be applied due to factors such as overcrowded classes, lack of technology, issues in pair and group work, and low English level of learners. Farooq's study tried to discover the perception, practices, and difficulties of applying CLT in the classroom. Therefore, "it is recommended that: - Teachers may prepare CLT activities, plan lessons, and create CLT environment to develop the communicative competence of the students" (Farooq, 2015, p. 188).

\section{English for Specific Purposes (ESP) Approach}

The necessity for a lingua franca related to science, technology, education, and business has originated the demand of ESP around the world. This approach has developed rapidly until it has become the main part of English language teaching and study. Consequently, understanding the necessities of other professions and readiness to get used to these necessities, make a certain group of students prepare differently since they use English for specific purposes. The ESP approach allows opportunities for the learners to learn English naturally in situations they understand and find interesting (Bracaj, 2014).

Hyland (2007) applied research methods (ethnography, critical approaches, contrastive rhetoric, and social constructionism) to study Role-play in ESP. He found that ESP classes help lectures to get highly connected to their future professional environments (Rojas, 2016). They help learners to develop communication strategies and to become more competitive in the job market.

\section{CONCLUSION}

The previous studies regarding the origins, definitions, contributions, and foreign language approaches involved in RP ratify the fact that, current trend develop students' speaking skills to perform authentic activities in which students are the active participants. The contemporary educational style is student-centered in which the learner is a dynamic member of his knowledge acquisition process and the teacher has lost his controlled power over the students.

RL has its origin in psychodrama which according to Moreno (1987) explores the real world through dramatization. In this respect, RP is the most used technique of psychodrama in the educational field in which the learner acquires knowledge naturally and meaningfully. During the RP preparation, students are encouraged to choose the keywords and expressions related to the context they want to resemble. This way, RP promotes the learners creativity by working collaboratively. Furthermore, RP is a communication technique that improves fluency by enabling students to interact in class and increase their motivation to learn.

Besides the contributions that RP provides to the development of the learners' speaking skills, it is supported by contemporaneous learning approaches such as TBLT which is a student-centered approach in which they are encouraged to produce meaningful messages in the target language. In TBLT activities such as RPs are authentic examples of what students will experience in the real world.

Another supported approach is CL since by working together learners develops their abilities to communicate socially and reach a common goal. In this regard, RP is a method in which students work collaboratively in groups with the instructor's help to dramatize a situation that it can also be experienced in a real context.

The third supporting approach for RP is CLT. In this approach instead of using the traditional methods of language teaching related to rules for correctness, meaningful messages are essential to communicate through language. Through RP students are encouraged to express the meaning instead of only focusing on the form of the message.

Finally, ESP is an approach that originated from the need for a lingua franca related to science, technology, education, and business worldwide. Therefore, ESP classes that implement RP enable students to function appropriately in genuine situations that relate to the specific purpose of the learners' career. Consequently, it allows opportunities to learn English naturally and meaningfully focusing on topics that are interesting and motivating for learners.

\section{REFERENCES}

[1] Alharby, H. A. (2015). Improving Students' English Speaking Proficiency in Saudi Public Schools. International Journal of Instruction 8.1, 105-115.

[2] Alhosni, S. (2014). Speaking Difficulties Encountered by Young EFL Learners. International Journal on Studies in English Language and Literature (IJSELL) 2.6, 22-30.

[3] Asensio, P. (2015). El jugador de rol en el entorno digital: Una nueva audiencia para las narrativas transmedia. Revista Sphere Publica 15. I, 34-56.

[4] Bracaj, M. (2014). Teaching English for Specific Purposes and Teacher Training. European Scientific Journal 10.2, 40-49.

[5] Branden, K. (2016). Task.Based Language Teaching. In G.Hall (ed.), The Routledge Handbook of English Language Teaching ( $1^{\text {st }}$ edn.). New York: Routledge, 238-245.

[6] Brecke, R. \& Jensen, J. (2007). Cooperative Learning, Responsibility, Ambiguity, Controversy, and Support in Motivating Students. InSight: A Collection of Faculty Scholarship. 2, 75-63.

[7] British Council, BC. (2004). Role-play [blog]. In:https://www.teachingenglish.org.uk/article/role-play.

[8] Bygate, M. (2015): Sources, developments and directions of task-based language teaching. The Language Learning Journal $44.4,381-400$. 
[9] Cevallos, J., Intriago, E., Villafuerte, J., Molina, G., Ortega, L. (2017). Motivation and Autonomy in Learning English as Foreign Language: A Case Study of Ecuadorian College Students. English Language Teaching 10.2, 100-113.

[10] Conforme, E. \& Torres, B. (2013). Consolidación de Destrezas con criterio de desempeño en primero de EGB (Bachelor's Dissertation). Universidad de Cuenca, Cuenca.

[11] Craciun, D. (2010). Role - playing as a creative method in science education. Journal of Science and Arts 10.1, $175-182$.

[12] Duxbury, J. \& Ling, T. (2010). The effects of cooperative learning on foreign language anxiety: a comparative study of Taiwanese and American universities. International Journal of Instruction, 3.1, 04-18.

[13] East, M (2017). Research into practice: The task-based approach to instructed second language acquisition. Language Teaching 50.3, 412-424.

[14] Farooq, M.U. (2015). Creating a Communicative Language Teaching Environment for Improving Students' Communicative Competence at EFL/EAP University Level. International Education Studies, 8.4, 179-191.

[15] Flores, A. \& Cedeno, L. (2016). Teaching methods in the English language learning. Journal of science and research 1. 3, 0712.

[16] Gass, S. \& Mackey, A. (2006). Input, interaction, and output: An overview. AILA Review 19.1, 3-17.

[17] Han, H. (2014). Transforming EFL Classes from Lecturing to Cooperative Learning. Journal of Language Teaching and Research 5. 4, 948-952.

[18] Huang, I. (2008). Role Play for ESL/EFL Children in the English Classroom. The Internet TESL Journal 14.2, 1-3.

[19] Hyland, K. (2007). English for specific purposes. In Cummins, J. \& Davison, C (eds.), International handbook of English language teaching ( $1^{\text {st }}$ edn.). New York: Springer, 391-402.

[20] Jackson, V. \& Back, A. (2011). Teaching Communication Skills Using Role-Play: An

[21] Experience-Based Guide for Educators. Journal of Palliative Medicine 14. 6, 775-780.

[22] Jacobs, G. M. \& McCafferty, S. G. (2006). Connections between cooperative learning and second language learning and teaching,. In: S. G. McCafferty, G. M. Jacobs \& A. C. DaSilva Iddings (Eds.), Cooperative Learning and Second Language Teaching. Cambridge: Cambridge University Press 18-2.

[23] Kumaran, S. (2017). Benefits and shortcomings of role-play as a speaking activity in English language classrooms. The English Teacher, 39.1, 72-93.

[24] Kusnierek, A. (2015). Developing students' speaking skills through role-play. World Scientific News 7.1, 73-111.

[25] Laguador, J.M. (2014). Cooperative Learning Approach in an Autcomes-Based Environment. International Journal of Social Sciences, Arts and Humanities 2.2, 46-55.

[26] Lee, C. D. \& Smagorinsky, P. (Eds.). (2000). Vygotskian perspectives on literacy research: Constructing meaning through collaborative inquiry. New York: Cambridge University Press.

[27] Mackey, A. (2006). Feedback, Noticing and Instructed Second Language Learning. Applied Linguistics 27.3, 405-430.

[28] Marin, J. \& Rea, C. (2014). Assessing four automatic term recognition methods: Are they domain dependent? Journal English for Specific Purposes 42.15, 1-27.

[29] Marin, M. \& De la Pava, L. (2017). Conceptions of Critical Thinking from University EFL Teachers. English Language Teaching 10.7, 78-88.

[30] Martinez, J. R. (2009). Influencia del Role-Playing en el proceso de enseñanza-aprendizaje de Enfermeria. (Doctoral Thesis, Universidad de Alicante, Valencia, España).

[31] Matamoros-Gonzalez, J.A., Rojas, M.A., Pizarro, J., Vera, S., \& Soto, S.T. (2017). English Language Teaching Approaches: A comparison of the Grammar-Translation, Audiolingual, Communicative, and Natural Approaches. Theory and Practice in Language Study 7.11, 965-973.

[32] Monsalve, M., Franco, M., Monsalve, M., Betancur, B., \& Ramírez, A (2009). Desarrollo de las habilidades comunicativas en la escuela nueva. Revista Educación y Pedagogía 21.55, 189-210.

[33] Moreno, J.L. (1987) Psychodrama and Sociodrama. In J. Fox (ed.), The Essential Moreno. Writings on Psychodrama, Group Method, and Spontaneity by J.L. Moreno, MD (pp. 13-19). New York: Springer Publishing Company, Inc.

[34] Moreno, J. (2017). Reflections on my Method of Group Psychotherapy and Psychodrama. In Greenwald, H. (Ed.), Experimentation and Innovation in Psychotherapy (pp. 130-135). New York: Routledge, Taylor \& Francis.

[35] Nation, I. \& Newton, J. (2009). Teaching ESL/EFL Listening and Speaking. New York:Routledge, Taylor \& Francis.

[36] Peko, A. \& Varga, R. (2014). Active Learning in Classrooms. Primljeno 15.1, 59-75.

[37] Perez, I. (2016). Mitología, cultura popular y juegos de rol. Revista El Futuro del Pasado 7.1, 219-237.

[38] Peterson, N., Pisoni, D., \& Miyamoto, R. (2010). Cochlear implants and spoken language processing abilities: review and assessment of the literature. Restor Neurol Neurosci 28.2, 237-250.

[39] Raja, H., Qureshi, R. \& Albesher, B. (2017). Application of Cooperative Learning Strategies (CLS) for Students' Focused Teaching (SFT) in EFL Class: An Experimental Study in the Summer Remedial Course for Adult Learners. Journal of Language Teaching and Research, 8.2, 237-252.

[40] Richards, J. \& Rodgers, T. (1986). Approaches and Methods in Language Teaching. New York: Cambridge University Press.

[41] Rojas, M.A., Villafuerte, J. \& Soto, S. (2017). Collaborative Work and Technological Means for Improving Learners' English Language Writing Production. TOJET: Turkish Online Journal of Educational Technology, Special Issue for ITEC 2017, pp. 92-105.

[42] Tran, V. D. (2014). The Effects of Cooperative Learning on the Academic Achievement and Knowledge Retention. International Journal of Higher Education, 3. 2, 131-140.

[43] Wafaa, A.Y. (2014). Cooperative Learning in the EFL Classroom. Proceeding of The 2014 WEI International Academic Conference, Austria, 92-98.

[44] Yen-Chen Yen, Huei-Tse Hou \& Kuo En Chang. (2013). Applying role-playing strategy to enhance learners' writing and speaking skills in EFL courses using Facebook and Skype as learning tools: a case study in Taiwan. Computer Assisted Language Learning 28.5, 383-406. 
[45] Zhang, Y. (2010). Cooperative Language Learning and Foreign Language Learning and Teaching. Journal of Language Teaching and Research 1.1, 81-83.

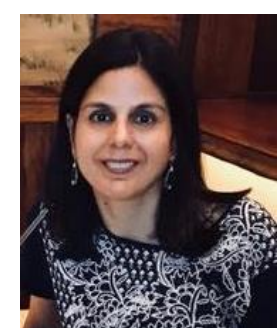

Maria A. Rojas is an Ecuadorian professor and researcher. In the year 2017 she earned a Master's Degree in Teaching English as a Foreign Language at Escuela Superior Politeécnica del Litoral (ESPOL) in Ecuador. Her major field of study focuses on English Language Teaching (ELT). She has been working as an ESP professor at Universidad Tecnica de Machala (UTMACH) in Machala, Ecuador since the year 2014. Prof. Rojas is a member of a Research Group called ELT Innovator at UTMACH. Some of her recent publications are: Collaborative Work and Technological Means for improving Learners' English Language Writing Production (Turkish Online Journal of Educational Technology, 2017), Performance-Based Tasks as a Mean to Assess the Speaking of Learners of English as a Foreign Language (Turkish Online Journal of Educational Technology, 2017), and English Language Teaching Approaches: A comparison of the Grammar-Translation, Audiolingual, Communicative, and Natural Approaches (Theory and Practice in Language Studies, 2017).

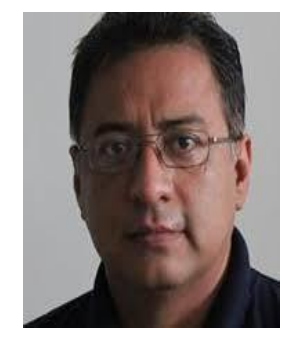

Jhonny S. Villafuerte, Ecuadorian researcher graduated from the Master's Program in Psycho Didactics from the University of the Basque Country, Spain; and from the Master's Program in Educational Research at Universidad Nacional de Loja, Ecuador. Other studies about education and local development were conducted in Chile, Brazil, USA, Germany, Belgium, Spain, England, Israel, Uganda, Mali, Russia, India and China. He is professor at the Laica Eloy Alfaro de Manabí University. His research lines are: Human and Sustainable Development; Educational Technology and language; Inclusive Entrepreneurship. His recently works are: La investigación cualitativa rutas para la puesta en práctica (book); Learners' Attitudes toward Foreign Language Practice on Social Network Sites (article); and Motivation and Autonomy in Learning English as Foreign Language (article). 